\title{
ЗМІСТОВИЙ АНАЛІЗ ДЕФІНІЦЇ̈ «ЕМОЦІЙНЕ ВИГОРАННЯ В СПОРТІ»
}

Стаття висвітлює основні характеристики дефініиії «емоиійне вигорання в спорті». У роботі здійснено теоретичний аналіз поняття. Зазначено, щзо на емочійне вигорання впливають внутрішні особливості професійної діяльності, стресові чинники спорту та індивідуальні характеристика спортсмена. Обгрунтовано щуо «емочійне «вигорання в спорті» $\epsilon$ вкрай складною психофізіологічною реакцією. 3 одного боку це механізм психологічного захисту від стресових факторів професійної діяльності. 3 іншого боку, синдром емочійного вигорання, відносять до професійних деформацій особистості, щяо трактуються як специифічний вид професійної деформації індивідуума.

Ключові слова: емочійне вигорання в спорті, стресові чинники, професійна діяльність, спортсмен.

Статья раскрывает основнье характеристики дефиниции «эмочиональное выгорание в спорте». Осуществлен теоретический анализ понятия. Отмечено, что на эмочиональное выгорание влияют внутренние особенности профессиональной деятельности, стрессовые факторы спорта и индивидуальные характеристика спортсмена. В статье обосновано, что «эмочиональное« выгорание в спорте »является крайне сложной психофизиологической реакиией. $C$ одной стороны это механизм психологической защиты от стрессовых факторов профессиональной деятельности. С другой стороны, синдром эмоционального выгорания, относят $\kappa$ профессиональным деформациям личности, которые трактуются как специфический вид профессиональной деформации индивидуума.

Ключевые слова: эмочиональное выгорание в спорте, стрессовые факторы, профессиональная деятельность, спортсмен.

Постановка проблеми. Психологічна готовність у спорті обумовлена достатньо стійкими психологічними особливостями, притаманними конкретному спортсмену. Професійний спорт характеризується великими навантаженнями, постійним знаходженням в умовах суперництва, неможливість впливати на прийняття рішень, одноманітна, монотонна діяльність, відсутність вихідних, відпусток і інтересів поза роботою. Ці фактори здійснюють руйнівний вплив на емоційну сферу висококваліфікованого спортсмена. У нього зростає кількість афективних розладів, з'являються почуття незадоволеності собою та своїм життям, труднощі у встановленні контактів з учнями, колегами, оточуючими людьми. Ці симптоми негативно відображаються на всій професійній діяльності спортсмена, погіршуються результати його роботи, знижується рівень задоволеності власною діяльністю. Таким чином відбуваються зміни у мотиваційній сфері і розвивається синдром емоційного вигорання.

Зниження психологічного потенціалу спортсмена вчені безпосередньо пов'язують із проблемою вигорання - станом, у структурі якого виокремлюють емоційне виснаження, деперсоналізацію, особистісні досягнення та конфліктність спортсмена [12]. Вигорання відбувається внаслідок дії тривалого або інтенсивного фізичного навантаження та проявляється в порушенні когнітивної, регуляторної та комунікативної функцій психіки, що складають психологічний потенціал спортсмена. Вигорання негативно позначається на якості тренувальної та змагальної діяльності спортсменів. Отже, застосування превентивних заходів, спрямованих на послаблення дії факторів, що зумовлюють появу симптомів вигорання спортсменів, а також систематичне проведення діагностичних досліджень, що дозволяють вчасно виявляти та застосовувати заходи корекції вигорання є одним із важливих завдань психологічної підготовки.

Аналіз останніх досліджень і публікацій. Вивчення змісту, структури та методів діагностики синдрому «емоційного вигорання» виконувалося у дослідженнях зарубіжних та 
вітчизняних вчених (М. Буріш, С. Джексон, К. Маслач, Х. Дж. Фрейденбергер, У. Б. Шауфелі, Л. М. Карамушка, М. П. Лейтер, С. Д. Максименко, В. Є. Орел, Т. В. Форманюк, В. В. Бойко, Н. Є. Водоп'янова, Т. І. Ронгинська, О. С. Старченкова, В. Дудяк та ін. Визначальним дослідницьким ракурсом аналізу здебільшого обираються фахові ознаки й специфіка їх прояву у представників різних професій - педагогів (В. КанКалик, Ю. Кулюткін, Н. Побірченко, Г. Сухобська, Н. Чепелєва, В. Чернобровкін, Т. Форманюк та ін), працівників міліції (І. Ващенко, 3. Кісіль, Л. Леженіна та ін.), спортсменів (К. Гренліф, В. Клименко, Г. Ложкін та ін.), працівників медичних закладів (К. Маслач, П. Бланк, В. Шуфелі та ін.), соціальних працівників (Дж. Грінберг, О. Полуніна, Б. Содерфельдт, М. Содерфельдт та ін.). Результати досліджень 3 виявлення специфіки структури вигорання у різних сферах професійної діяльності, показали, що його трикомпонентна структура трансформується в залежності від типу професійної діяльності та має певні особливості прояву в межах кожної професії [10]. Що ж стосується високваліфікованих спортсменів, то це питання ще достатньо не досліджене.

Мета дослідження - охарактеризувати емоційне вигорання та визначити його особливості в професійному спорті.

Реалізація мети передбачає виконання таких завдань дослідження: здійснити теоретичний аналіз поняття «емоційне вигорання» та визначити його особливості в спортивній діяльності; охарактеризувати вплив стресу у сфері спортивної діяльності на емоційне самопочуття спортсменів.

У роботі використовувались такі теоретичні методи дослідження: аналіз, порівняння, систематизація, узагальнення теоретичних і експериментальних даних.

Виклад основного матеріалу дослідження. Будь-яка діяльність людини, відображується на іiі особистості, залишає відбиток на особистісних якостях, формує свідомість. Під впливом деформуючих факторів діяльності (навчальної, професійної, спортивної та ін.) формується синдром «емоційного вигорання». Зауважимо, що термін «професійне вигорання» вперше використав американський психіатр Х. Дж. Фрейденбергер для позначення психічного стану здорових людей, які постійно перебувають у емоційно перенавантаженій атмосфері у зв'язку 3 тим, що їх професійна діяльність вимагає інтенсивного спілкування. У психологічній літературі проблема професійного вигорання розглядається у межах трьох основних напрямів: що це явище є виявом синдрому хронічної втоми, стану фізичного, психічного, емоційного виснаження, який є наслідком тривалого перебування в емоційно перевантажених ситуаціях спілкування; професійне вигорання - це двовимірна модель, що складається 3 емоційного виснаження та деперсоналізації; трикомпонентна система, що охоплює емоційне виснаження, деперсоналізацію; редукцію особистісних прагнень [1].

Процес розвитку професійного вигорання - це поступове накопичення негативних емоцій, котрі не мають адекватного виходу, особистість демонструє зростання напруги у спілкуванні з колегами по роботі, друзями та знайомими; поступово емоційна хронічна втома переходить у фізичну; спостерігаються розлади сну і як наслідок - людина не має сили працювати. Поступово хронічна втома викликає стан апатії та депресії, спалахи роздратування, почуття напруги, дискомфорту. Погоджуючись iз американськими дослідниками К. Маслач і С. Джексон, вважаємо, що професійне вигорання - це синдром емоційного виснаження, деперсоналізації і редукції особистих досягнень [5-7].

Модель професійного вигорання Б. Пармана, Е. А. Хартмана складається із чотирьох стадій, а іï автори окреслюють цей феномен як фізичний та психологічний дискомфорт. Синдром має три фази: «напруги», «резистенції» та «виснаження», кожна 3 яких включає в себе симптоми: переживання психотравмуючих обставин; незадоволеність собою; «загнаність у клітку»; тривога і депресія; неадекватне вибіркове емоційне реагування; емоційно-моральна дезорієнтація; розширення сфери економії емоцій; редукція професійних обов'язків; емоційний дефіцит; емоційна відторгненість; особистісна відторгненість; психосоматичні і психовегетативні порушення. 
Для діагностики професійного вигорання використовують широкий спектр методик. Зокрема, методика О. Рукавішнікова «Визначення психічного «вигорання» дозволяє вивчити три основні рівні психологічної перевтоми - міжособистісний, особистісний, мотиваційний. Ця методика містить 72 твердження щодо відчуттів, пов'язаних 3 роботою.Психодіагностичні завдання об'єднані у 3 шкали Шкала психоемоційного виснаження (ПВ) діагностує зниження емоційних, фізичних, енергетичних ресурсів професіонала, що виявляється у хронічній емоційній, фізичній втомі, байдужості та холодності у ставленні до людей, наявності ознак депресії та роздратованості. Шкала особистісного відсторонення (OB) - специфічна форма соціальної дезадаптації професіонала, що супроводжується зменшенням кількості контактів 3 оточенням, підвищенням роздратованості й нетерплячості в ситуаціях спілкування, негативізмом у спілкуванні 3 іншими. Шкала професійна мотивація (ПМ) спрямована на діагностику рівня професійної мотивації й ентузіазму у діяльності з альтруїстичним змістом. Стан емоційної сфери оцінюють за показниками продуктивності професійної діяльності, зацікавленістю нею, рівнем оптимізму та характером самооцінки власної активності, успішністю взаємодії 3 людьми. Кількісна оцінка психічного вигорання за кожною шкалою здійснюється шляхом перетворення відповідей у трибальну систему і сумарного підрахунку балів, а нормативна таблиці визначає рівень психічного вигорання.

Діагностика емоційного вигорання за методикою російського психолога В. В. Бойка це вияв напруження, резистенції та виснаження. Респондентам пропонують відповісти на 84 запитання, кожне з яких відповідає одному із провідних симптомів вигорання. Критерій «напруження» спрямований на діагностику відчуття емоційної виснаженості, втоми, зумовленої професійною діяльністю. Основними симптомами напруження є сприйняття людиною умов своєї праці, професійних та міжособистісних стосунків як психотравмуючих; поява незадоволеності собою як особистістю та професіоналом; виникнення відчуття безвихідності ситуації, бажання змінити професійну діяльність; розвиток тривожності, посилення нервових і депресивних настроїв. Резистенція як надмірне емоційне виснаженням, провокує виникнення та розвиток захисних реакцій, які формують людину як емоційно закриту систему, відсторонену, байдужу, а будь-яке емоційне залучення до професійних справ і спілкування викликає у неї відчуття перевтоми. Третій компонент характеризується психофізичною перевтомою, спустошеністю, нівелюванням власних професійних досягнень, порушенням професійного спілкування, розвитком цинічного ставлення до професійної когорти, психосоматичними порушеннями. Відповідно до запропонованого «ключа» підраховується суму балів окремо для кожного з 12 симптомів вигорання; суму показників симптомів для кожної з 3-х фаз формування вигорання; підсумковий показник синдрому емоційного вигорання - це сума показників усіх 12-ти симптомів. За показником виразності прояву кожного із симптомів визначається фаза сформованості емоційного вигорання. Характеризуючи основні теоретико-методологічні положення оптимізації змісту і структури навчально-тренувального процесу спортсменів високої кваліфікації ряд науковців [4; 9; 12 ; 16] зазначає, що провідною ланкою для зростання їхньої майстерності, важливого значення набуває психологічна підготовка.

Отже, щоб успішно виступити на змаганнях, спортсмен повинен мати певний рівень не лише фізичної, але й психологічної підготовки. Досить часто вирішальним для перемоги у змаганнях є саме психологічна підготовленість спортсмена і вміння керувати собою у стресових ситуаціях [8; 9; 13-16]. Існує декілька підходів у розумінні сутності стресу. Перш за все обговорюється ідея його процесуальності. Зокрема, автор теорії стресу Г. Сельє розглядає його як «загальний адаптаційний синдром», наголошуючи, що «стрес - це не просто нервове напруження». Стрес (процес стресу) - це інтегральна (глобальна) відповідь організму і особистості на екстремальні впливи (стресори) або на підвищене навантаження. У динаміці стресу виділяють три фази:

- фаза тривоги, напруженості й первинного (часто надмірного) збудження у відповідь на стресор; 
- фаза резистентності (пристосування) - адаптації організму до подразників (стресорів);

- фаза виснаження, неузгодженості в діяльності систем, а потім "поломка" окремих 3 них.

Основними чинниками стресу у спортивній діяльності є: гостра конкуренція під час спортивної боротьби, що спрямована на встановлення рекорду або перемогу над супротивником; максимальне фізичне й психологічне напруження під час цієї боротьби; систематичні, тривалі й інтенсивні спортивні тренування, що суттєво впливають на режим життя та побут $[2 ; 4 ; 13 ; 15]$. Аналіз літератури показав, що можно виокремити два різновиди стресу у спортсменів: соціально-емоційний та тренувальний. Перший (соціально-емоційний стрес) полягає у взаєминах 3 тренером та іншими спортсменами. Другий (тренувальний стресс), пов'язаний із максимальними фізичними й психологічними напруженнями під час змагальної діяльності; систематичні, тривалі й інтенсивні спортивні дії із значними фізичними навантаженнями [16]. Стрес-фактори, які суттєво впливають на спортивні результати та найчастіше зустрічаються в спортивної діяльності за часовим критерієм також поділяють на дві підгрупи: передзмагальні та змагальні.

До стрес-факторів, що виникають напередодні змагання відносять наступні чинники:

- попередні незадовільні тренувальні та змагальні результати.

- конфлікти з тренером, товаришами по команді або в сім'ї;

- положення фаворита перед змаганнями;

- поганий сон за день або кілька днів до старту;

- погане матеріальне забезпечення змагань;

- попередні невдачі;

- завищені вимоги;

- тривалий переїзд до місця змагань;

- постійні думки про необхідність виконання поставленого завдання;

- незнайомі суперники;

- попередні поразки від певного суперника.

У науковій літературі багато уваги приділяється також другому типу стрес-факторів напруженню, що виникає у процесі змагань [4; 13]. Стрес-фактори, що виникають у процесі спортивних випробувань подані у таблиці 1.

Таблиця 1

Основні групи стрес-факторів

Сутнісні характеристики стрес-факторів, що виникають у процесі змагань та спортивних випробувань

\begin{tabular}{|l|l|l|l|}
\hline 1 & Невдачі на старті & 7 & $\begin{array}{l}\text { Несподівано високі результати } \\
\text { суперника }\end{array}$ \\
\hline 2 & Необ'єктивне суддівство & 8 & Глядачі, акустичні і тактильні перешкоди \\
\hline 3 & Відстрочка старту & 9 & Реакція глядачів \\
\hline 4 & Докори під час змагання & 10 & Погане фізичне самопочуття \\
\hline 5 & Підвищене хвилювання & 11 & $\begin{array}{l}\text { Больовий фінішний синдром, } \\
\text { страх травмування чи смерті }\end{array}$ \\
\hline 6 & Значна перевага суперника & & \\
\hline
\end{tabular}

Науковцями встановлено зв'язок між рівнем психологічного стресу у спортсменів і результативністю змагальної діяльності $[14 ; 15]$. Фізичне перевантаження може негативно впливати на емоційний стан спортсмена. При емоційній нестабільності спортсмена фізична робота значної потужності не сприяє зростанню спортивно-технічної майстерності. Хронічний стрес спричиняє перетренування. Систематичне перетренування своєю чергою призводить до емоційного «вигорання». Цей стан у спортсменів є наслідком постійної емоційної та фізичної втоми, він виникає в осіб із сильною мотивацією, які інтенсивно тренуються i змагаються у несприятливих умовах протягом тривалого часу. Основними 
індикаторами психологічної втоми є депресія, дратівливість, негативне мислення і втрата інтересу до різних аспектів життя [2; 4; 9].

Згідно з аналізом наукових досліджень цієї проблеми: основні зусилля психологів спрямовані на вияв чинників, що спричиняють професійне вигорання. Здебільшого синдром «емоційного вигорання» досліджується у так званій «групі ризику». У відповідну групу включають представників професій системи «людина-людина», які в межах своєї діяльності перебувають у процесі постійного тісного спілкування. У науковій літературі наявні різні думки щодо природи та психологічних механізмів виникнення цього феномену. 3 одного боку, синдром емоційного вигорання розглядають як механізм психологічного захисту від стресових факторів професійної діяльності. Уважається, що особистість людини - цілісна та стійка структура і їй властиво шукати способи захисту від деформації. Одним із засобів такого психологічного захисту і є синдром емоційного вигорання. 3 іншого боку, синдром емоційного вигорання, відносять до професійних деформацій особистості, що трактуються як специфічний вид професійної деформації осіб.

Спорт, як професійна діяльність, характеризується високими фізичними і психічними навантаженнями, орієнтацією на досягнення максимально високих результатів, жорсткою конкуренцією суперників. Людина, яка відбулася у цій професійній діяльності, має не тільки кар'єрні плани професійного зростання, але і значні фактори ризику надбання професійної втоми і інших негативних наслідків. Окремі дослідження засвідчують, що існує можливість негативного впливу професійної праці на особистість суб'єкта діяльності. Негативний вплив специфічних чинників професійної діяльності на особистість працівника в літературі має визначення професійних деструкцій в структурі професійної деформації особистості.

На думку провідних вчених [4-6], професійну деформацію спостерігають, насамперед, у професійному середовищі «людина - людина», до якого відноситься і професійна діяльність спортсмена [4]. У науковій літературі термін «професійна деформація» особистості в психологічному контексті інтерпретується таким чином: це зміни якостей особистості (стереотипів сприйняття, ціннісних орієнтацій, характеру, способів спілкування та поведінки), які починаються під впливом тривалого виконання професійної діяльності. Щоденне, виконання впродовж багатьох років одних і тих самих завдань (професійна діяльність в умовах одноманітної роботи в тому числі під час численних тренувальних зборів, стресові ситуації під час змагальної діяльності тощо) формує професійні звички, певний тип мислення, світобачення й стиль спілкування. Психологічний механізм формування феномену професійної деформації визначають як проникнення «Япрофесійного» в «Я-людське». Тому навіть в особистому житті людина продовжує нести на собі «деформуючий відбиток» своєї професії» [3].

Певні риси характеру особистості і поведінкові моделі збільшують схильність тієї чи іншої людини до вигоряння. Більшість спортсменів є надзвичайно мотивованою групою, тому емоційне вигоряння у них може стати причиною формування негативних Я-концепцій, зміни ставлення до роботи, людей, втрати ідеалів і мети. Такі риси та моделі поведінки $\epsilon$ визначальними в емоційному вигорянні: 1) перфекціонізм; 2) орієнтація на інших; 3) відсутність позитивних стосунків [2; 12; 13]. Крім того, синдрому емоційного вигорання набувають жінки-спортсменки, які переживають внутрішнє протиріччя між роботою й родиною, а також перебувають у пресингу у зв'язку з необхідністю постійно доводити свої професійні можливості в умовах конкуренції із чоловіками.

У зв'язку з цим розширення уявлення про психолого-педагогічні детермінанти «емоційного вигорання» у спортсменів високої кваліфікації, узагальнення та систематизація даних, які спричиняють виникнення та сформованість «емоційного вигорання, є особливо актуальним питанням сучасної психології.

Висновки та перспективи подальших розвідок. Проведений аналіз наукової література показав, що висококваліфіковані спортсмени, які знаходять себе у професійному спорті входять до так званої «групи ризику» працівників, які найбільш схильні до вигорання 
Емоційне «вигорання»є вкрай складною психофізіологічною реакцією, спричиненою частими надмірними й малоефективними зусиллями спортсмена задовольнити надмірні вимоги. На нашу думку емоційне вигорання в спорті необхідно розглядати в аналітичному розрізі індивідуальних характеристик спортсмена та внутрішніх аспектів їхньої професійної діяльності. Перспективи подальших розвідок ми вбачаємо у подальшому аналізі функціональної ролі кожного симптому емоційного «вигорання» (базові та ведучі симптоми) на структурному рівні.

\section{Список використаних джерел}

1. Бойко В. В. Синдром эмоционального выгорания: диагностика и профилактика / В. В. Бойко. - СПб. : Питер, 2008. - 336 с.

2. Бондаревська Л. Вплив травмуючих переживань на виникнення психічного / Л. Бондаревська // Психологія і суспільство. - 2008. - № 2. - С. 185-188.

3. Воробйов М. І. Психологічний супровід педагогічної діяльності викладача фізичного виховання у процесі його професійного становлення / M. І. Воробйов, Т. В. Петровська, А. А. Кравченко // Актуальні проблеми фізичної культури і спорту : зб. наук. пр. - Київ, 2007. - Вип. 13. - С. 73-79.

4. Воронова В. І. Психологія спорту : навч. посіб. / В. І. Воронова. - Київ : Олімп. літ., 2007. -298 с.

5. Картузова А. А. Профессиональная деформация личности: определение понятия / А. А. Картузова // Педагогика, психология и медико-биологические проблемы физического воспитания и спорта. - 2007. - № 3. - С. 48-51.

6. Мардахаев Л.В.Профессиональная деятельность и деформация личности / Л. В. Мардахаев. - М., 2001. - 160 с.

7. Маслач К. Профессиональное выгорание: как люди справляются [Електронний pecypc] / К. Маслач. - Режим доступу : http://mirznanii.com/a/204675-1/professionalnoevygoranie-kak-lyudi-spravlyayutsya.

8. Орёл В. Е. Синдром психического выгорания личности / В. Е. Орёл. - М. : Издво «Ин-т психологии РАН», 2005. - 330 с.

9. Павлова Ю. Відновлення у спорті : монографія / Ю. Павлова, Б. Виноградський. - Львів : ЛДУФК, 2011. - 204 с.

10. Современные проблемы исследования синдрома выгорания у специалистов коммуникативных профессий : коллектив. моногр. / под ред.: В.В.Лукьянова, Н. Е. Водопьяновой, В. Е. Орла и др. - Курск, 2008. - 336 с.

11. Трунов Д. Г. «Синдром згоряння»: позитивний підхід до проблеми / Д. Г. Трунов // Журнал практичного психолога. - 1998. - № 5. - С. 29-37.

12. Черникова О. В. Эмоциональные состояния в спорте / О. В. Черникова // Спортивная психология в трудах отечественных психологов / [сост. И. П. Волков]. - СПб. : Питер, 2002. - С. 73-78.

13. Gould D. Psychological stress and the agegroup wrestler / D. Gould, L. Pettichkoff // Competitive sports for children and youth / E. W. Brown, C. F. Branta (eds). - Champaign : Human Kinetics, 1988. - P. 63-73.

14. Kallus K. W. The Recovery-Stress Questionnaires: User Manual [Manual] / K. W. Kallus, M. Kellmann ; Pearson Assessment \& Information GmbH. - 2016. - 356 p.

15. Kellmann M. Review Preventing overtraining in athletes in high-intensity sports and stress/ recovery monitoring / M. Kellmann // Scand J Med Sci Sports. - 2010. - Oct. (№ 20) (Suppl. 2). - S. 95-102.

16. Vasylyuk V. Psychological Properties and Stress Tolerance of High-Qualified Athletes Specializing in Athletic Walking [Electronic resource] / V. Vasylyuk, O. Yarmoschuk, C. Yudkina // Path of Science. - 2018. - № 4 (4). - Access mode :

http://dx.doi.org/10.22178/pos.33-3. 


\section{References}

1. Bojko V. V. Sindrom jemocional'nogo vygoranija: diagnostika i profilaktika / V. V. Bojko. - SPb : Piter, 2008. - $336 \mathrm{~s}$.

2. Bondarevs"ka L. Vplyv psyxotravmuyuchyx perezhyvan" na vynyknennya psyxichnoho vyhorannya / L. Bondarevs"ka. - Kiev : Lybid", 1996. - S. 59.

3. Vorobjov M. I. Psyxolohichnyj suprovid pedahohichnoyi diyal"nosti vykladacha fizychnoho vyxovannya u procesi joho profesijnoho stanovlennya / M. I. Vorobjov, T. V. Petrovs"ka, A. A. Kravchenko // Aktual"ni problemy fizychnoyi kul"tury i sportu : zb. nauk. pr. - Kiev, 2007. - Vyp. 13. - S. 73-79.

4. Voronova V. I. Psyxolohiya sportu : navchal"nyj posibnyk / V. I. Voronova. - Kiev : Olimpijs"ka literatura, 2007. - 298 s.

5. Kartuzova A. A. Professional'naja deformacija lichnosti: opredelenie ponjatija / A. A. Kartuzova // Pedagogika, psihologija i mediko-biologicheskie problemy fizicheskogo vospitanija i sporta. - 2007. - № 3. - S. 48-51.

6. Mardahaev L. V. Professional'naja dejatel'nost' i deformacija lichnosti / L. V. Mardahaev. - M., 2001. - 160 s.

7. Maslach K. Professional'noe vygoranie: kak ljudi spravljajutsja [Elektronnij resurs] / K. Maslach. - Rezhim dostupu : http://mirznanii.com/a/204675-1/professionalnoe-vygoranie-kaklyudi-spravlyayutsya.

8. Orjol V. E. Sindrom psihicheskogo vygoranija lichnosti / V. E. Orjol. - M. : Izd-vo «Institut psihologii RAN», 2005. - $330 \mathrm{~s}$.

9. Pavlova Yu. Vidnovlennya u sporti : monohraf. / Yu. Pavlova, B. Vynohrads"kyj. Lviv : LDUFK, 2011. - 204 s.

10. Sovremennye problemy issledovanija sindroma vygoranija u specialistov kommunikativnyh professij : kollektivnaja monografija / pod red.: V. V. Luk'janova, N. E. Vodop'janovoj, V. E. Orla ; Kursk. gos. un-t. - Kursk, 2008. - 336 s.

11. Trunov D. H. «Syndrom zhoryannya»: pozytyvnyj pidxid do problemy / D. H. Trunov // Zhurnal praktychnoho psyxoloha. - 1998. - № 5. - S. 29-37.

12. Chernikova O. V. Jemocional'nye sostojanija v sporte / O. V. Chernikova // Sportivnaja psihologija v trudah otechestvennyh psihologov / [sost. I. Volkov]. - SPb. : Piter, 2002. - S. 73-78.

13. Gould D. Psychological stress and the agegroup wrestler / D. Gould, L. Pettichkoff // Competitive sports for children and youth / E. W. Brown, C. F. Branta (eds). - Champaign : Human Kinetics, 1988. - P. 63-73.

14. Kallus K. W. The Recovery-Stress Questionnaires: User Manual [Manual] / K. W. Kallus, M. Kellmann ; Pearson Assessment \& Information GmbH. - 2016. - 356 p.

15. Kellmann M. Review Preventing overtraining in athletes in high-intensity sports and stress/ recovery monitoring / M. Kellmann // Scand J Med Sci Sports. - 2010. - Oct. (№ 20) (Suppl. 2). - S. 95-102.

16. Vasylyuk V. Psychological Properties and Stress Tolerance of High-Qualified Athletes Specializing in Athletic Walking [Elektronnyy resurs] / V. Vasylyuk, O. Yarmoschuk, Kh. Yudkina // Path of Science. - 2018. - № 4 (4). - Rezhym dostupu : http://dx.doi.org/10.22178/pos.33-3.

Pavelkiv R.V., Vasilyuk V.M., Yudkina Kh.V. CONTENT ANALYSIS OF DEFINITION «EMOTIONAL BURNOUT IN SPORTS».

In modern conditions, the psychological aspects of the preparation of high-class athletes are of great importance, which determines the search for ways, means and methods aimed at achieving the optimal state of readiness and successful implementation of the human body's capabilities in extreme situations.The article highlights the main characteristics of the definition of "emotional burnout in sport». In the work the theoretical analysis of the concept of "emotional burnout» was made. It is noted that emotional burnout is influenced by internal features of professional activity, stress factors of sport and individual characteristics of an athlete. 
The conducted analysis of scientific literature has shown that highly qualified athletes who find themselves in professional sports are part of the so-called "risk group" of workers who are most prone to burnout. It is substantiated that "emotional burnout in sport» is a very complicated psycho-physiological reaction. On the one hand, it is a mechanism of psychological protection against stress factors of professional activity. On the other hand, the syndrome of emotional burnout refers to professional deformations of the person, which are treated as a specific form of professional deformation of an individual. It is proved that emotional burnout in sport should be considered in the analytical section of the individual characteristics of the athlete and the internal aspects of their professional activities.

Key words: emotional burnout in sports, stress factors, professional activity, athlete.

УДК 159.923.5

Ж. П. ВІРНА, К. О. ПОВАР

\section{СТАТЕВОРОЛЬОВА ІДЕНТИФІКАЦІЯ ЯК ЧИННИК ПСИХОЛОГІЧНОГО БЛАГОПОЛУЧЧЯ СІМЕЙНОГО ПОДРУЖЖЯ}

Стаття присвячена вивченню статеворольової ідентифікації в межах визначення психологічного благополуччя сімейного подружжя. Теоретичний аналіз проблеми вміщує розгляд особливостей статеворольової ідентифікаиії особистості та специффіку переживання психологічного благополуччя сімейного подружжя. Емпірична експлікачія проблеми розкрита через визначення зв'язку статеворольової ідентифікації та психологічного благополуччя сімейного подружжя. На основі розробленої емпіричної програми вивчення проблеми з'ясовано зміст прояву маскулінності, фремінності $i$ андрогенності у благополучних (конструктивних) $i$ неблагополучних (деструктивних) сімейних парах.

Ключові слова: статеворольова ідентифікачія, психологічне благополуччя, сімейне подружжся, маскуліннсть, фемінність, андрогінність, благополучні (конструктивні) сімейні пари, неблагополучні (деструктивні) сімейні пари.

Статья посвящена изучению полоролевой идентификащии в пределах определения психологического благополучия семейных пар. Теоретический анализ проблемы вмещает рассмотрение особенностей полоролевой идентификации личности и специфику переживания психологического благополучия семейных пар. Эмпирическая экспликация проблемы раскрыта через определение связи полоролевой идентификации и психологического благополучия семейных пар. На основе разработанной эмпирической программы изучения проблемы выяснено содержание проявления маскулинности, феминности и андрогенности в благополучных (конструктивных) и неблагополучных (деструктивных) семейных парах.

Ключевые слова: полоролевая идентификачия, психологическое благополучие, семейные nары, маскулинность, феминность, андрогенность, благополучные (конструктивные) семейные пары, неблагополучные (деструктивные) семейныле пары.

Постановка проблеми. Аналіз психологічного благополуччя сімейного подружжя набирає усе більше обертів у межах соціально-психологічних досліджень. На фоні різких соціально-економічних змін в суспільстві саме підтримка позитивного, сприятливого клімату в сімейному середовищі є запорукою не лише сімейного, а й загального життєвого комфорту особистості. Також у межах психологічних досліджень сучасної сім’ї і сімейних відносин, усе гостріше заявляють про себе такі феномени порушення партнерської комунікації як страх психологічної інтимності, синдром «емоційного холоду» i «токсичної любові», міжособистісна залежність / контрзалежність тощо, які суттєво порушують процеси становлення психологічного благополуччя особистості, яке, в свою чергу, є інтегральною характеристикою їі якості життя. 